\title{
The Transfer Price Conundrum
}

Virginia Anne Taylor, (Email: taylorv@wpunj.edu), William Paterson University

\begin{abstract}
International transfer pricing issues are the subject of this paper. The transfer price is the price of goods and services traded between related companies, often through cross-border transactions. The huge and growing volume of tangible and intangible goods involved in transfer pricing situations makes this an important area of study.
\end{abstract}

\section{INTRODUCTION}

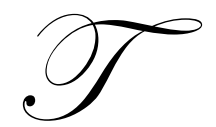

oday globalized markets, international foreign direct investment, and worldwide procurement combine to create a complex, integrated and dynamic business environment. Transfer prices are the value assigned to intermediate goods, which move between the divisions of a vertically integrated firm. The transfer or movement of raw materials, parts, or partially finished goods may occur in the context of either national or international production process. Intra-firm trade which includes services, technology, capital goods, intermediate goods, and finished goods for resale, constitutes a significant portion of world trade. The accounting and economics literature, government documents and business publications have been reviewed to uncover the underlying rationale for various government regulations. They indicate the principle objective of transfer price regulation is the appropriate and transparent reporting of the true product costs associated with these goods. In general, governments constrain transfer pricing decision choices through trade policy, foreign direct investment incentives, labor law, foreign exchange rates, currency regulations, local content requirements, and traditional business practices.

\section{MOTIVES FOR TRANSFER PRICE MANAGEMENT}

Governments worry about domestic welfare, especially in election years. The tax, accounting, reporting, and regulatory agencies also look for reporting transparency and consistency across countries. The multinational firms want to maximize shareholder value through higher stock prices, a function of current and long tern profits. To this end they try to minimize taxes.

As Williamson (1975) pointed out, when a firm expands its operations either domestically or internationally, transactions are influenced by the visible hand of managerial authority rather than the invisible hand of the competitive price system. Accordingly, one of the primary advantages of a multinational firm versus a domestic corporation lies in its flexibility to transfer resources across boarders through a globally maximizing network (Kogut, 1983). "It is clear is that the potential for tax arbitrage that results from globalisation creates a considerable and continuing incentive for domestic companies to internationalize their business (Plinder \& Simon, 2004)". Since transfer prices are the value assigned to intermediate goods, which move between the divisions of a vertically integrated firm, the fact that they are, related party transactions between organizational units can reduce the expected macroeconomic benefits. Intra-firm trade differs from basic arms length transactions between unrelated parties because it is shaped by the global parent's strategy to control upstream supplies and downstream markets (Encarnation, 1994; Eden, 1994). Plinder and Simon's (2004) recent investigation suggests transfer pricing threatens global tax revenues, they conclude the "tax authorities face substantial difficulties in unraveling complex operations between subsidiaries of multinational groups". Back in 1973 this kind of trade accounted for one third of all US goods (Lall, 1973). By 1996 US intra-firm trade with overseas manufacturing affiliates reached $\$ 243$ billion (Monthly Bulletin of Statistics, 1998). This trend has not been limited to US firms; Department of Commerce figures, worldwide two-way intra-firm trade increased from 102 billion in 1977 to 337 billion (Tang, 1990). Regional trade agreements such as NAFTA and the European Union accelerate the trend (Zwick, 1998). In 2004 intra-company trade among corporate subsidiaries "accounted for $46 \%$ of the $\$ 1.33$ trillion US imports and 31\% of $\$ 731$ billion in exports (Sunday Tribune,2004). 
From social responsibility and a welfare economics focus, free trade implies all should receive due benefits. However, a plethora of reasons to use transfer pricing to determine the location of profit recognition exists.. On the one hand external constraints arise from stakeholders in home or host country constitutes to move or hide profitability. As early as 1973 Lall posited the home country of a multinational may gain unfairly at the expense of a less developed host country. On the other hand international politics may create a climate for a strategy to move profits via transfer pricing even if this means taxes and tariffs are higher. As shown in Figure 1 the motivation for transfer price manipulation tend to fall into a few general categories: profits, politics, and financial issues

Figure 1: Transfer Price Management

\section{Transfer Price Motivation}

Profits: taxes, union demands, government subsidy.

Politics: local content rules, political stability, citizenship.

Finance: foreign exchange volatility, diversification, capital cost.

Various conditions have been found to be particularly conducive to the formation of a global transfer price strategy. The MNE can use transfer pricing strategies to avoid or mitigate local content requirements, qualify for special treatment or avoid other legal barriers. Often a profit or loss in one center is "transferred" to another division when tariff and subsidy conditions exist. Alternately, MNE can use transfer prices to diversify risk across countries and currencies thereby lowering the discount premium on cash flows. Risk reduction via diversification gives global firms the ability to obtain below market rates on financial lending and hedging lower cost making them more competitive and efficient. Transfer prices can be manipulated to avoid or minimize the effect of tariffs and local content regulations. The local government may impose a higher or lower tax rates (Phillips, 2001) and actively engage in foreign exchange speculation. Empirically, Arpan (1972) found that management views transfer pricing as a tool to minimize taxes and more importantly to circumvent foreign exchange restrictions. International business diversification has created a need and opportunity for foreign exchange risk management. From a social responsibility and a welfare economics focus, free trade implies all countries should receive due benefits. However, Lall (1973) posited the home country of a multinational may gain unfairly at the expense of a less developed host country. He explains how conceptually transfer price manipulation reduces host country welfare; because gains from foreign direct investment are less than would have been.

\section{CALCULATION METHODS}

This sections of the paper investigats both the reasons why and the various ways measurement differences can arise under current accounting rules. One problem is the ambiguity created by multiple definitions resulting in a lack of a common understanding about what constitutes the true product cost basis. Although accounting research shows that legal compliance with tax law is a major determinant of the multinational firms' transfer price policy, the Australian Tax Office found it "intriguing" that $60 \%$ of all multinationals doing business in that country reported losses (1999). There are several permitted transfer pricing methods listed in The Tax Executive, November/December 2003) In general the rules applied to goods, services and intangible property are largely analogous. The five transfer pricing methods shown in Figure 1 are often referred to as Section 482 rules, named after the United States IRS code.

Figure 2: Transfer Price Calculation

\section{$\underline{\text { Transfer Price Methods }}$}

CUP - the Comparable Uncontrolled Price Method.

Cost + Cost Plus - this method includes a reasonable markup.

Resale Price Method uses the price in an open market.

Profit Split Method applies a ratio between HQ and the branch.

BALM - Basic Arms Length Method (IRS preferred method). 
As globalization and trade liberalization trends continue to emerge, even small firms find themselves doing business in more than one tax jurisdiction (Carter, 1998); they too must learn to navigate the international transfer price jungle and to use transfer pricing as a tool to open more strategy alternatives. Back in 1976 Nieckles suggested international agreements on how multinationals should be taxed globally and how to allocate those taxes among those countries in which they operated Ten years ago Ernst \& Young (1991) suggested consistency in application and economic justification are the best way to defend the reasonableness corporate policy and resultant transfer prices in tax court. Firms still run the risk of time consuming audits, severe adjustments and costly penalties. Only half the multinationals in more recent audits were able to defend their transfer pricing methods. Solid transfer price documentation translates directly into bottom line (Bobbin, 1998). Lopatin (2003) suggests it is really impossible to know how much tax a transnational corporation has paid in each jurisdiction or territory. Therefore, transfer pricing manipulation will flourish as long as there is "no obligation to report the split between third-party and intergroup trading.

\section{SUMMARY AND CONCLUSIONS}

As the number of worldwide cases imply there is a growing sense on the part of many governments that multinational firms engage in transfer pricing abuse. Evolving national and regional rules on global transfer pricing policies present a twofold challenge for the multinational firm, the management challenge to maximize profits and the regulatory challenge to provide a well documented and defensible transfer pricing policy. This study uncovered a plethora of reasons for multinational enterprise price manipulation when reporting of intra-firm transactions. Transfer pricing is a tool which allows amplification of strategies and opens new strategies to multinational firms not available to domestic firms. Trade restriction, taxation, exchange rate volatility, and foreign direct investment act as drivers of corporate transfer price policy. The public evidence and economic data that were examined uncovered multiple industrial transfer price practices. As the evidence demonstrates, proper pricing of goods that move between subsidiaries is anything but simple. Transfer price studies consistently find tax compliance; performance evaluation and financial controls emerge as important considerations. (Tang 1993, Ernst \& Young 1991, Borkowski 1990; Springsteel, 1999). Trade restriction, taxation, exchange rate volatility and foreign direct investment act as drivers of corporate transfer price policy. To prove compliance with government regulations, international firms are expected to both justify the reasonableness of corporate policy and demonstrate consistent application. In short global transfer pricing policy requires systematic analysis, purposeful thinking, and careful orchestration. It is a never-ending process.

This work should be of value to both other researchers who seek better understanding of the dynamics of transfer pricing and to corporate managers who seek proof of compliance with state regulators. This research is both interdisciplinary and applied in the sense that it affects more than one discipline or profession, international managers, economic policy makers, and accounting professionals. Hopefully these findings provide a beginning step for harmonization of international accounting standards. One set of rules would lead to more efficiency and increased transparency in reporting the localization of value-added activity.

\section{REFERENCES}

1. Arpan, J. (1972), International Intracorporated Pricing: Non-American Systems and Views, Prager, New York.

2. Bobbin Group, 1998, Transfer pricing audits:it's sweaty palm time. November, www.findarticles.com.

3. Borkowski, S. (1990) Environmental and Organizational Factors Affecting Transfer Pricing: A Survey, Journal of Management Accounting Research, V: 2 (Fall) pp. 78-99.

4. Carter, W.K., 1998. The problem of transfer pricing: when you have facilities in more than one jurisdiction Journal of Accountancy, July, www.findarticles.com.

5. Eden, L. 1994, Multinationals in North America, Calgary: University of Calgary Press.

6. Encarnation, D., 1994, Intra-firm trade in North America and the European Community in Eden, L. Multinationals in North America, Calgary: University of Calgary Press, pp. 323-327.

7. Ernst \& Young, 1991, International Transfer Pricing, New York: Business International. 
8. Lopatin, M. Big Business Still Dodging the Tax Issue, The Observer, 12 January 2003, http:// observer.co.uk/business/story/0,6903,872940,00.html.

9. Monthly Bulletin of Statistics, 1998, Washington DC:US Department of Commerce, Table D p.267 .

10. Nieckels, L., Transfer Pricing in Multinational Firms: A heuristic programming Approach and a Case Study, John Wiley \& Sons, New York, 1976.

11. O.E.D.C. International Investments and Multinational Enterprises, Organization for Economic Co-operation and Development, Paris, 1976.

12. Phillips, M. M. 2001, U.S. to review role in assault on tax havens, Wall Street Journal 2/23.

13. Plender, J and M. Simons 2004, A big squeeze for governments: how transfer pricing threatens global tax revenues, Financial Times (London, England) July 22.

14. Section 482 of the Internal Revenue Code: Allocation of Income and Deductions Among Taxpayers.

15. Springsteel, I. 1999, Separate but unequal (transfer pricing), CFO the magazine for senior financial executives, April, www.findarticles.com.

16. Tang, R., Transfer Pricing in the 1990's, Management Accounting, February/1992, pp. $22-26$.

17. Tang, R. Transfer Pricing in the 1990's: Tax and Management Perspectives, Quarom, Westport, Conn. 1993

18. The Tax Executive, November/December 2003.

19. Williamson, O., 1975, Markets and Hierarchies, New York: The Free press.

20. Zwick, S. 1998, WTO probe is sought on local content, American Metal Market, 8/24 www.findarticle.com. 